\title{
Analyzing Present Cultural Relevance between India - West Asia Relations
}

\author{
Sudhanshu Tripathi* \\ Professor of Political Science, U.P. Rajarshi Tandon Open University (UPRTOU), India
}

Submission: March 31, 2018; Published: May 24, 2018

"Corresponding author: Sudhanshu Tripathi, Professor of Political Science, U.P. Rajarshi Tandon Open University (UPRTOU), Allahabad, UP, Pin210013, India, Tel: 91-9838137686; Email: sudhanshu.tripathi07@gmail.com

\begin{abstract}
As West Asia is an extended part of the Greater Asia and do have some of the defining common geographical footings resulting into, perhaps, the closest social, religious, economic and political similarities, the cultural roots between India and West Asia, obviously, indicate towards the inevitable stark similarities between them because no other country in the Asian continent have had as long and sustained historical engagement with the West Asia as that of India and that underlines the significance of present day relevance between their mutual relations and that makes their historic engagement unique and unparalleled. Obviously their mutual friendly relations will be very useful not only for their own peace, prosperity and security alone but for the whole world because both regions of the Asian continent are very rich with respect to natural resources and cultural diversities as well.
\end{abstract}

Keywords: India; West Asia; Arabs; European; Civilization; Customs; Traditions; Cultural relations; Contemporary relevance; Ethnic; Politics

\section{Introduction}

Asia is a large and diverse continent next only to Africa not only in terms of geographic specificities but also with respect to abundance of social, economic, cultural and political diversities. There are an abundance of ethnic groups throughout Asia, with adaptations to the climate zones of Asia, which can be humid, subtropical or tropical. The ethnic groups have adapted to mountains, deserts, grasslands, and forests. On the coastal lines of Asia, the ethnic groups have adopted various methods of harvesting and transportation. Here some groups were primarily prehistoric hunters or herdsmen or husbandmen afterwards, following a nomadic lifestyle and gradually practicing agrarian and rural culture for millennia and in later ages adopting industrial and modern urban consumer culture for comfort and pleasure. The considerably vast spread of the continent is divided into many geographic and cultural regions and such sub-regions, viz. Central Asia, East Asia, North Asia, South Asia, Southeast Asia, and West Asia. Similarly, the culture of Asia is diverse which manifests itself into different kinds of cultural heritage of different societies, ethnicities and also of nationalities as regards societal conglomerates, ethnic diversities, cultural norms and civilization origin and growth. Culturally, though there is a relatively little unity or common history for cultures and peoples of Asia with as regards art, music, language, religion cuisine and literature etc., but there mutual interactions and relationships play a significant role in the evolution of Eastern philosophy characterized by different religions viz. Hinduism, Confucianism, Taoism, Buddhism, Judaism and also Islam; altogether known as Orientalism which signifies a clear departure from the Western world [1]. Nonetheless, one of the most complex parts of Asian culture is the presence of near close similarities between traditional cultures of the Asia with that of the West, on the one hand. But, on the other hand, despite the aforesaid diversities in Asia, there exists an essential bond of unity underlying all across different characteristic features of the Asian continent, perhaps due to broad similarities - more or less - with respect to almost identical genes of different human race and also near common climatic and geographical features including same nature of soil and water, thereby leading to evolve a marked cultural homogeneity within the manifest diversity of different customs and traditions. Out of these, the cultural roots between India and West Asia point towards some of the stark similarities between them because no other country in the Asian continent have had as long and sustained historical engagement with the West Asia as that of India [2].

The article explores the presence of the long standing socio-cultural relations between India and West Asia which has evolved in these two geographic entities since the dawn of civilization and continues today unabated. Though the mutual relations between them are manifold and diverse with respect to climate, ethnic groupings, social attitude and preferences, 
religious diversities and rituals, economic activities and political organizations, as the second part details, but the underlying similarities between the two have tied them altogether so as to evolve a mixed partnership as regards common endeavor towards peace and security, economic growth and prosperity and fight against terrorism including ISIS terror menace. The next part discusses geographic and socio-cultural specificities of the two (India \& West Asia) and their similarities which together have put considerable impact upon Indian as well as West Asian culture and civilization. Lastly, the article concludes with highlighting the significance of present day relevance of the mutual relations between India and West Asia which make their historic engagement unique and unparalleled.

\section{Mutual socio-economic engagement}

And that engagement continues unhampered till today in various aspects of day to day human life and their common affairs as regards art, music, literature, religious practices and the common efforts towards economic progress and prosperity, peace and security and fighting the menace of terrorism and religious fundamentalism of all shades and forms in the region, because West Asia may be considered as an extended part of Greater India i.e. Bharatha varsha in South Asia [3]. According to Amartya Sen, "Indian culture, as it has evolved, has always been prepared to absorb ideas and material from elsewhere. Cultural influences are, of course, a two way process, and India has borrowed from abroad, just as it has given the world outside the accruing benefits of the indigenous cooking traditions. For example, while tandoori came from the Middle East to India [4], it is from India that tandoori has become a staple British diet. Given the cultural and intellectual interconnections, the question of what is 'Western' and what is 'Eastern' (or 'Indian') is often hard to decide, and the issue can be discussed only in more dialectical terms. The diagnosis of a thought as 'purely' Western or 'purely Indian' can be very illusory." Similarly, the mutual economic and trade relations between them are also of great importance as India is a major importer of crude oil from the region and that has provided a major source of employment and sustenance to the millions of Indian nationals living therein.

\section{Geo-political significance of West Asia}

In the middle of overlapping definitions according to geopolitical and economical perspectives, West Asia today occupies a very significant place in the global politics due to its geographic, strategic, economic, political and religious importance, particularly due to being a confluence of three religions - Judaism, Christianity and Islam as important religious centre's like Mecca, Medina, Jerusalem, Qualm etc. are situated in this region. Being a land of some of the prominent ancient civilizations viz. Egyptians, Assyrian, Turkish and Arab, people in the region interact among themselves through four main languages called as Arabic, Persian, Hebrew and Turkish. Also commonly known 'Middle East' [5] there is no consensus about the geographical expanse of this region which extends from Turkey,
Egypt, Iran and Persian Gulf and the entire Arabian Peninsula including other countries of Asian continent that touches the European and African continent. As such the Middle East is so complex and fluid an area that its boundaries as a region are subject to debate. Roughly, it extends from Turkey (in the West) to Afghanistan (in the East). Its prominent members includes Algeria, Turkey, Egypt, Syria, Iraq, Iran, Saudi Arabia, Israel and the whole of Arabian Peninsula. It is strategically important and continues to be highly insecure and volatile region due to long continuing macabre violence and terror which is going on unrestrained for the past many decades. As the historical records prove that militancy and terror have their close connection with West Asia ever since Arab Muslims began exerting their hegemonic control over Palestine - a British mandate then - in their bid to uproot Jews who were then gradually consolidating themselves as Zionist movement to secure their homeland, after the Balfour Declaration in 1917. Also commonly known 'Middle East' there is no consensus about the geographical expanse of this region which extends from Turkey, Egypt, Iran and Persian Gulf and the entire Arabian Peninsula including other countries of Asian continent that touches the European and African continent are termed as 'West Asia'. As such the Middle East is so complex and fluid an area that its boundaries as a region are subject to debate. Roughly, it extends from Turkey (in the West) to Afghanistan (in the East). It includes Turkey, Egypt, Iran and the whole of Arabian Peninsula.

\section{India's manifold relations with the West Asia}

As the ancient historical sources testify that India did share a long and deep historical relationship with West Asia as India's manifold relations with the West Asian countries evolved against this backdrop. In fact, India and West Asia has pre-historical ties since trade relations were established between civilizations of Mesopotamia and Indus Valley \& Harappa. But these relations have deeper roots too as both of them have strong economic and commercial ties coming down since ages. One of mankind's oldest maritime trading routes ran from ancient Sumeria via Bahrain to the Indus Valley civilization and Harappa, arguably called meluhha by West Asians, was one of their active trading partners. In fact, the British imperial interests with respect to Persian Gulf were preserved through India and at that time countries like Kuwait and Oman used the rupee as genuine tender for exchanging commodities and goods in normal human chores. In fact, it was India which contributed the number system and so were the West Asians who developed the counting method of numbers in the world. Even the advent of Muslims and Islam into India was through this region which has today evolved as the Hindu-Muslim or Ganga-Jamuni culture of mixed etiquette and courtesy paving way for emergence of Sufism and other liberal-humanist Muslim sects in India and such liberal sects in West Asia. Thus, there is a long history of intellectual, political and commercial interactions which has left an indelible imprint on the Indian and West Asian cultures [6]. And that link became more prominent during the medieval period when art, 
architecture and literature of both sides fused to take the so evolved cultural heritage to higher levels.

In medieval times, comments a noted scholar MS Agwani [7], "the Indian expertise in medicine, mathematics and astronomy was highly valued by Arab and Iranian scholars who eventually made it part of their own intellectual tradition. Conversely, India imbibed a great deal from the Arab, Iranian and Turkish cultures; and much of it has become an inextricable part of the Indian cultural ethos. The intrusion of European Powers in Asia in the nineteenth century snapped some of these links but that only temporarily. Finally, their common resistance to colonial rule in the first half of this century brought the Indians, the Arabs, and the Iranians closer to one another in their historic Endeavour to become masters of their own destinies. And it is on these foundations that the whole edifice of political, economic and cultural relations between India and the West Asia has been built" during decades after independence of the country.

\section{Conclusion}

Today West Asia stands as a region of considerable significance for India [8], economically as well as strategically. The region is home to more than 7 million Indians, who contribute around US $\$ 40$ billion in remittances annually. The region is a source for more than 60 per cent of our oil and gas requirements, and hence critical for our energy security. The Maghreb region is a major source of phosphate and other fertilizers, a significant factor in our food security. The ongoing fierce battle between different warring groups in Syria, Libya, Yemen, Israel, Palestine, Lebanon, etc., were further layered by the Iranian nuclear negotiations and the ever mounting upsurge of ISIS terror, despite the US led western powers air strikes along with that of Russia's too, have put the whole region not only in a state of the gravest flux, uncertainty and insecurity but have seriously endangered the peace and security of the whole world. But fortunately India's position remains guided by its long cherished goals of peace and non-interference into the internal affairs of other states and it consistently maintains constructive and friendly \& cordial relations with all the countries of the region. Thus, as a result of India's historical ties and principled approach of foreign affairs from ancient times to the present, India has been able to maintain its traditional yet progressive relations with the West Asian region and that shall, in all likelihood, help build a strong foundation of peace, friendship and cooperation between them thereby paving way towards progress and welfare of the entire humanity. This is possible as nothing is beyond human endeavor.

\section{References}

1. Gupta S P (1970-71) 'Gulf of Oman: The Original Home of Indian Megalitis', Puratattva 4: 7

2. Nehru J L (1946) The Discovery of India. John Dey (US): Meridian Books, UK.

3. Muller Max (1879) The Sacred Books Of the East, Oxford University Press, UK.

4. Chaudhari, Pratim Pal (2016) India's Middle Path in the Middle East Asian Waves.

5. Guisepi R (1998) The Rise Of Civilization In The Middle East And Africa. A project by History World International, World History Center.

6. Sen, Amartya (2005) The Argumentative Indian: Writings on Indian History. Allen Lane/ Penguin, UK.

7. Agwani M S (2015) Indo-West Asian relations: Towards expanding horizons. India Today, New Delhi, India.

8. Basham A L (1954) The wonder that was india. Sidgwich and Jackson, UK.

Your next submission with Juniper Publishers
will reach you the below assets
- Quality Editorial service
- Swift Peer Review
- Reprints availability
- E-prints Service
- Manuscript Podcast for convenient understanding
- Global attainment for your research
- Manuscript accessibility in different formats
( Pdf, E-pub, Full Text, Audio)
- Unceasing customer service
Track the below URL for one-step submission
https://juniperpublishers.com/online-submission.php

